\title{
OSLO 2019: A CAR-FREE CITY CENTRE
}

\author{
ULF RYDNINGEN, REBECCA CELINE HØYNES \& LARS WISTH KOLLTVEIT \\ Oslo and Akershus University College of Applied Sciences, Department of Civil Engineering, Norway
}

\begin{abstract}
In June 2016, a climate and energy strategy for Oslo was enacted by the city council. The overall climate targets adopted for Oslo 2030-2050 were to reduce greenhouse gas emissions by 50\% (2030) and to zero in 2050. To achieve these goals, several measures for the various municipal sectors have to be implemented. For the transport sector, the most important measure is to ensure transition from individual car transport to public transport, cycling and walking, green goods transportation. Having a fossil free society in 2050, then it is crucial to reverse trends to changing people's behaviour. If car traffic inside the city centre will be banned, then the consequences need to be evaluated. The concern for the disabled, goods transportation, public transit and residents must be safeguarded. Through comparison with other cities that are partially car-free, we have described some consequences that must be taken into account when implementing the green policy. Several methods are used, a literature review and face-to-face interviews. A study-tour to Germany and France included city-walks, and interviews with urban and transport planners and politicians from the cities of Nuremberg, Freiburg, and Strasbourg. These cities were chosen because of their log experience with implementation of pedestrianized city centres. The provision of pedestrianized city centre in Oslo may at first glance seem like a political stunt from an inexperienced visionary political party. Drastic measures must be implemented, that requires thoughtful planning and participation. A car-free city centre cannot be completed at the expense of the population, and to have a good planning phase will be more important than the goal of implementing the measures within a certain time limit. Achieving good accessibility for all affected may potentially lead to a vibrant cityscape, suitable for many.

Keywords: car-free, Oslo city centre, urban development, sustainable transport.
\end{abstract}

\section{INTRODUCTION}

The transportation sector accounts for the largest share of greenhouse gas emissions in Oslo. In 2012, it constituted $63 \%$ of the total Oslo greenhouse gas emissions, of which passenger transport emissions are the main source [1]. Oslo is predicted to grow by nearly 200,000 residents over the next 20 years [2]. If this population growth is not decoupled from private transport growth, it will lead to an increase in greenhouse gas emissions. These emissions are expected to grow totally by $15 \%$ by 2030 . The only way to avoid this development, is to implement more sustainable measures for the transport sector.

In January 2015, the municipality of Oslo presented a draft of a climate and energy strategy, which was effectuated in June 2016. Two of the overall climate targets adopted for Oslo were as follows: In 2030, Oslo's direct greenhouse gas emissions be reduced by $50 \%$, relative to 1991 levels. This corresponds to an emission reduction of 600,000 tonnes of $\mathrm{CO}_{2}$. In 2050, Oslo's direct greenhouse gas emissions will be zero [1]. To achieve these goals, the city council's proposition suggests several measures for the various municipal sector-programs. For the transport sector, the most important measures are to ensure transition from individual car transport to public transport, increased cycling and walking, more green transport of goods, and phasing out fossil fuel, and also transport-reducing urban planning for attractive and vibrant local areas [1]. The proposition also points out the importance of planning and implementation of "fossil-free streets and areas" in Oslo [1], [3]. In October 2015, the Oslo city council presented a declaration claiming that "Oslo shall be Europe's Environment Capital... People deserve a more vibrant city life, cleaner air, more bike paths and better public transport" [2]. The city council has a consistently green vision, 
and set ambitious new goals that are unreachable unless drastic measures are implemented. Such measures will affect many people in and outside Oslo. One of the city council's efforts in order to achieve its climate targets, is to reduce all traffic in Oslo by $20 \%$ during the council period, and by one third by 2030 compared with 2015 . To achieve this, car accessibility and car ownership must be less favourable. Not only should fossil-free streets and areas be planned and executed, but the city council decided: "The city council will make the city centre within Ring 1 pedestrianized during the council period" [2]. This is a decision which will have major social consequences.

As many other cities, Oslo has a ring road system. The car-free zone is to include the entire area within the innermost ring, Ring 1 . The area is $1.9 \mathrm{~km}^{2}$, and includes the central railway station, Oslo's main commercial streets, shopping malls, major nightlife districts and about 90,000 jobs (2015) and 1063 residents (2015) [4]. As a large number of people are staying in or travelling through the Oslo city centre every day, all these will be affected. The amount of jobs and the number of residents in the centre indicates that most who visit the city centre are commuters. How much the various user groups and stakeholders will be positively or negatively affected by the introduction of pedestrianized city centre depends on factors like place of residence, travel habits, disability and profession. The city council says that: "Consideration of reduced mobility, goods transport, public transport, residents and transportation to important social functions must be safeguarded, and the city council will invite businesses, residents and other stakeholders to dialogues on implementation. The city council will draw on expertise from other cities, and gather experience through pilot projects" [2].

\subsection{Research question}

Oslo City Council has decided that Oslo will be car free without having investigated the consequences or proposed concrete detailed measures. Our task is therefore to gather information from various user groups and stakeholders, to determine how they may be affected by the various measures that can accompany a pedestrianized city centre. Through comparison with other cities that already have implemented partially car-free city centres, we describe what must be taken into account to ensure that the measures will not affect user groups and stakeholders in a negative way. Our research question is: "How might different user groups and stakeholders be affected by a traffic-free centre of Oslo?" To answer this question, we look to other cities with pedestrianized centres, and we talk to various user groups and stakeholders who are expected to be particularly affected by the plans.

\subsection{Limitations}

In this study, we mainly consider the area inside the Ring 1 and how user groups and stakeholders will be affected by the planned changes here. Regarding public transport, commuters, and travel habits, we have focused on travels ending in the city centre. Our study focuses on those we think would be most affected by the provision on the pedestrianized centre. These are user groups and stakeholders, who depend on good accessibility even in a future pedestrianized city centre. We have covered the following user groups, stakeholders and travel modes: travellers, public transport, trading and service industry, goods deliveries, craftsmen, and the disabled. We have not dealt with emergency vehicles or technical services like waste collection vehicles, winter maintenance vehicles and vehicles for cleaning of streets, as these are services which we assume must access the area within Ring 1, even with a ban on motorized vehicles. 


\section{METHODS AND DATA}

Mixed method is particularly suitable when the results of one method can be enhanced by using another, and since neither qualitative nor quantitative methods are sufficient to answer the questions for our study.

An introductory literature review has been conducted, mainly to learn from the policy-making and planning processes in other cities that have completed development of car-free city centres/streets and for comparing with Oslo.

Fieldwork is regarded as an essential method of learning from others, and represents one of the most effective and enjoyable forms of learning [5]. We conducted a study tour to the cities of Nuremberg, Freiburg and Strasbourg. We chose these cities because they have well-known pedestrianized city centres. The cities we visited have a relevance to Oslo because they are relatively large and have undergone transformations of the city centres and thereby caused changing travel habits of residents. The study tour was a way for the group to experience cities which are car-free, and observe the implemented measures. Through this study tour we got the chance to interview people working with urban and traffic planning in these cities.

The selected interviewees were from various disciplines, cities and user groups. Most are protagonists in their field and had the opportunity to speak on behalf of the user groups and stakeholders they represent. We interviewed six people for this study: Gunnar Larssen CEO Oslo Commercial Association, Bendek Maartman-Moe deputy director of strategy by the state-owned company responsible for the Norwegian national railway infrastructure, Magnhild Sørbotten regional manager Norwegian association of disabled in Oslo, John Hinnecke urban planner in Nuremberg, Dr. Peter Pluschke manager for the Nuremberg unit for environment and health, and Dr. Peter Schick traffic planner in Freiburg. We tried repeatedly to get in touch with various Oslo City Council representatives and members of the Oslo Green Party, to get a statement concerning questions of objectives, actions and tangible considerations. They have been unwilling to respond, and asked us to wait until the project organization for the project was completed. This is probably because the project is in its infancy and that the specific measures are not clarified. As a result, we only have information based on what has been written in the Oslo City Council's declaration.

We have been in contact with several user groups and stakeholders who have not had the opportunity to participate in an interview. They have however been able to answer some of our questions through mail correspondence. This has given us answers to their opinions on action to be undertaken.

\section{CAR-BASED URBAN DEVELOPMENT}

The relationship between car and city have influenced urban planning models worldwide over the past 100 years. Since the car first appeared in the streets, city planners and government have made a huge effort to adapt cities to drivers' needs, particularly in terms of the two main requirements; to move as quickly as possible and to park close as possible to the destination. Sidewalks and pedestrian crossings were built to prevent conflict between people and cars. What previously had been free movement of pedestrians became restrictions where cars had priority. The conflict between the car and the rest of urban living in many places has reached the level that it is incompatible with quality of life and sustainability [6]. In the book Carfree Cities, Crawford [7], writes: "The damage of cars to community forms the foundation of my argument: urban cars are anti-human". According to Crawford, the only real solution to the problem is to introduce totally car-free cities. The car-free city offers a more sustainable, healthier and happier future, much more than you might gain by improving cars or limiting traffic [7]. Pedestrian streets and the city centre can thus be used 
as a strategy for a pleasurable urban environment. The dominance of car traffic in the city centre can be significantly reduced without compromising the city's accessibility and economy. In fact, better opportunities for internal movement of pedestrians and a positive urban environment has proven to be the best conditions for success. The city's attractiveness depends on its ability to offer something special, and a wide range of activities; shopping, dining and entertainment. Parking regulations, together with good accessibility for pedestrians, cyclists and public transport is the most effective way to ensure good mobility and well-being [6].

\section{EXPERIENCE GAINED FROM CAR-FREE CITIES}

There are many differences between the car-free cities we've seen for this study and Oslo, both in terms of population, size and urban structure. The planned pedestrian area in Oslo is considerably larger than the car-free area in the other cities. The streets in these cities are also very unlike the street network in Oslo. The cities we have looked at are older historic cities with many narrow streets that are not suitable for cars. Parts of the towns have high historical value and there are therefore few things that can be done with street designs. Yet these cities are largely relevant to Oslo, given the measures taken to change travel habits and making centres to safe and attractive places for pedestrians [8].

\subsection{Strasbourg}

Strasbourg is a city in France with 274,390 inhabitants (2014). During the 1980s the city was characterized by growing traffic-related problems; much queuing, air and sound pollution and high accident levels. In the early 1990s, it was therefore decided to make efforts to limit the number of private cars in the city. It upgraded public transport, while the pedestrian zone in the centre was expanded. In addition, heavy traffic was removed from the centre. Both goods delivery and residents' access to the heart of downtown was limited. Parking fees were introduced, while cyclists and pedestrians were given free access to all areas. Shop owners in the city centre were major opponents of the changes. They feared for fewer customers due to reduced car accessibility. The outcome of the changes in the city showed that after a break-in period even motorists converted. The expanded public transport system led to a significant shift from private car to public transport. The number of cyclists increased too. Gradually, the major resistance groups were also in favour of the scheme. The project did not result in any significant loss in revenue the shops, rather the contrary [9].

During our city walk early in the morning we observed several vehicles in the streets. Most of these were goods distribution vehicles. We also observed the distribution of goods with alternative delivery methods. The centre had a good public transport system where the trams running through the town were very quiet and drove slowly through pedestrian zones. Trams and tram-stations seemed to be universally designed. Many of the historic streets were too narrow to be suitable for vehicular traffic. These were developed as bike routes, and the town also had a city bike system. The city was well signposted with maps of the pedestrian zones. We observed no taxis inside the pedestrian zone and many of the streets had restaurants that used the streets for dining. There are several parking garages inside the old town with ties to the pedestrian streets.

\subsection{Freiburg}

Freiburg is a city in Germany with about 220,000 inhabitants. In the late 1960s the city experienced increasing problems with air pollution caused by traffic. This led to a growing 
commitment among residents to limit car traffic. In 1975 it was decided to shut down car traffic in the main street in the centre. Tram lines and pedestrian zones were significantly expanded. Vehicular traffic was moved to ring roads outside the city centre, and commuter parking spaces were created with connection to public transport. In 1989 the municipality came with a plan to reduce car traffic further. The main elements of the plan were to invest in parks instead of street parking, in lanes for public transport only, signal prioritization and increasing park and ride [10]. The cycle network in Freiburg was also significantly expanded, and currently has a total distance of $420 \mathrm{~km}$.

During our city walk in Freiburg we observed a well-established public transport system. Most trams were universally designed, racers had separate bicycle paths and buses had stops adjacent to the tram. In connection with the tram stops at the edge of the city, we observed commuter parking spaces. The parking lots were filled with cars, which may indicate that the park and ride is a popular offering. The city had a well-developed pedestrian and cycle system, with wide roads and a steady stream of both cyclists and pedestrians. Some streets were dedicated cycle paths where pedestrians do not have access.

During the visit to Freiburg we met traffic planner Peter Schick. He works on projects that embrace planning of any car, bicycle and public transport in the city. He described the town as Germany's ecological capital, since it has had enacted environmentally friendly policies since the 1970s. In the 1960/70's, residents figured out that the city had to initiate measures to reduce vehicular traffic because of environmental considerations, partly because the forest that embraced the city was dying. The measures that were built, resulted in an expanded public transport system with new tram lines and hubs around the city. A wide cycle network and associated bicycle parking was another instrument that decreased car traffic. Despite this development, the centre still is the main hub for public transport. Dr. Schick also emphasized that everyone is different and that the bike does not suit all, while public transit is universally designed. The cars are no longer as polluting as they were, and there are electric and hybrid cars. The main reason for Freiburg wanting a reduction in cars is no longer because of the damage to the natural environment, but for improvement of the urban environment. Upon release of land that was previously used to motorized traffic, one can also meet population growth's need for housing. To maintain trade in the centre, there is a ban on the creation of large shopping malls outside the city [11].

\subsection{Nuremberg}

Nuremberg is a German city with about 500,000 inhabitants (2007). In the early 1970s Nuremberg's city centre had a growing problem with traffic-related air pollution causing decay of historic buildings and health concerns. In 1972, pedestrian network extended to large parts of the commercial district. The city was divided into five districts where cars could not run directly from one to the other. Shop owners thought downtown would be closed off for potential visitors, but the percentage of shoppers rose significantly. This was due to several factors. A new subway and its commuter parking enhanced availability from the outskirts, while $9 \mathrm{~km}$ of pedestrian streets improved internal accessibility. City parking remained about the same, but was better organized for the benefit of visitors and residents [9].

During the visit to Nuremberg, we had a guided tour with John Hinnecke, urban planner in Nuremberg. He showed us streets that were previously reserved for cars have been "closed" for private vehicle traffic and are now based on the principle of shared space for pedestrians, cyclists, buses and taxis. During our tour of the city, we observed several parking garages and parking lots, which the municipality is struggling to get rid of. Some of the streets in town were reserved exclusively for pedestrians. In these streets, cyclists were not allowed 
entrance, and these streets only permitted for taxis in certain time periods. Some places in the city were marked bike paths. Where the speed limits were low, cyclists and motorists shared the road. Goods delivery is only allowed until 10:30 am and we observed no distribution vehicles in the streets at noon. There were certainly instances of both private cars and work vehicles in the car-free streets. The car-free streets were thriving with stalls and with festivity. John Hinnecke told us about cultural life, which had been strengthened by having streets pedestrianized. Every year there is a festival where there are several concerts in the pedestrianized streets [11].

During our interview with Peter Pluschke, politician and commissioner for health and environment representing the Green Party, we asked about the reasons for making parts of the city pedestrianized. He confirmed that it was due to poor air quality in the 1980s. They changed the system radically in the city centre, and also undertook changes on the outside. One can still get around all over the city by car, but it is hard. When asked whether this caused many protests, he replied in the affirmative, but in general there was agreement among the parties and the population that a change was necessary. Most of the resistance came from shopkeepers and restaurant industry. The traffic system changed at the same time as there were major changes in commerce, as several of the older individual shops were replaced by international chain stores. It was fortunate for them, as there was not as much opposition from the new stores and the new generation of shopkeepers, although he believes that it took about 10 years to find a new balance. It was feared that people would go elsewhere than downtown to shop, but this did not happen. The city centre has a varied offer, shoppers also take a coffee or go to a museum. Many want to have a varied experience. He believes this is one of the factors that keeps people in the city.

We asked whether stakeholders had the opportunity to come with their views and demands, the answer was clearly yes. It was essential to invite them to participate in the planning process. It was the plan from the very beginning that the buses would have run in the car-free streets, but not taxis. There were so many complaints from taxi drivers, that the city decided that taxis, to a certain level, were part of the public transport. Some private cars also run through the car-free area, but there are very few. The police are not very strict on it. They keep an eye on it, but in a relaxed way. "I do not vote strongly for intervention always. You must leave everybody a certain freedom to organising their life. And I think this is one of the lessons we had to learn, that you cannot determine everything, you must leave room for the people to move like they want to move, within certain limits" [11]. Deliveries and craftsmen must have access. Nuremberg has solved it such that goods delivery must take place before 10:30 am. It took some time before this was accepted, but now the big companies mostly adhere to the rules, with a little more variation with the small ones. Craftsmen must get permission in advance to drive and park in pedestrianized areas after 10:30 am. Cyclists are not allowed in pedestrian areas, but this is not being adhered to. "Defending the space for pedestrians is always a big job" [11]. The advantage of making the city car-reduced is that the quality of life for the 30,000 city residents is much better. Finally, when asked if he had any ideas for how Oslo could achieve it, his advice was to have a relaxed attitude. You talk about a car-free city, but there will always be some cars there. "Never do it 100\%, think always about an $80 \%$ or $90 \%$ solution" [11].

\section{SOME AFFECTED USER GROUPS AND STAKEHOLDERS IN OSLO}

\subsection{Residents}

There are 1063 people living within Ring 1. This area is the area in Norway with the lowest average proportion of cars per household, and only $44 \%$ of the population here has access to 
parking. According to the national travel survey 2013/14, sixty percent of the population in the Oslo area lives within 500 meters from a bus-stop for public transport, and for $47 \%$ a public transportation that runs four times an hour. In the centre of Oslo, only $17 \%$ of the population are traveling by car, while walking share is $43 \%$. The city council's proposition says there should be reserved parking for resident in neighbourhoods in the inner city, and fees on all municipal parking lots within Ring 2. This means that anyone using a car in Ring 1, will have to pay for parking if they do not have parking in connection with their residence [2], [12], [13]. Oslo's population growth over the next few years is estimated that there will be a need for up to 100,000 new homes by 2030 [14].

\subsection{Travelers - Motorists and cyclists}

According to the city council's statement, pedestrians, public transport users and cyclists should gain priority over motorists. In the Oslo area shopping and service travels represent the largest share of daily tips (29\%). Second largest is commuting and leisure travel, while school trips, business travel, companion and goods travel, and home visits are less than $10 \%$. Despite the fact that shopping and service travels constitute the highest percentage compared to all daily travel, there are very few of these automotive trips ending in Oslo city centre. Only $10 \%$ of journeys to work by car end in the centre.

For Oslo to be a cycling capital, bicycling needs good facilitation. The topography in Oslo is uneven, and many are reluctant to ride uphill. By enabling to bring a bike on public transport, there is a greater chance that people choose the bike instead of the car [15].

\subsection{Parking}

Within Ring 1 there are 924 street parking places and 6600 spaces in parking garages. To avoid traffic in the city, municipal strategy has for several years been increasing possible parking garage adjacent to the Ring 1, and shortened the parking time and heightened the parking fees for spaces that lie within Ring 1 [16]. The city council's strategy says that street parking that conflicts with bike route development will be removed [2]. By turning the car parking spaces into routes and parking for bicycles, it will be easier for the cyclists to ride their bikes safely and also accommodate more parked bicycles than cars. [17]. By removing street parking and reducing vehicle access, much road space will be released.

\subsection{Public transportation}

Ruter is a publicly owned company responsible for public transport in Oslo and neighbouring county Akershus. Ruter determines fares and routes for subways, trams, buses and ferries in the two counties, which are then run by various operators. Existing public transport services in the city centre consists mainly of tram, metro and bus. Annually there are 319 million individual journeys being made, which are organised by Ruter. The current public transit system in Oslo is built around the central railway station, which allows all rail traffic to pass through the station. With so much traffic concentrated in one place, it can cause a full stop if there are problems on the rail network [18]. A goal for the public transit system, organised by Ruter, is to become a fossil-free company in 2020. This is a project Ruter calls "Project Fossil Free 2020". The project assumes a move away from fossil fuels for both buses and ferries. This is a project that will contribute to the climate goals that the city council has set for Oslo.

Ruter had no opportunity to attend an interview, but the press contact, Øystein Dahl Johansen, answered some of our questions by email. Here it emerged that Ruter believes that 
the capacity of the existing public transport is adequate even when the area within Ring 1 is closed to private vehicles. On the issue of whether a pedestrianized city centre will be a positive change in the urban environment and whether it will create a growth in public transport, he says: "It is difficult to say in advance how this will turn out. But it's quite possible this will affect public transport positively, both in terms of better accessibility for buses and trams, and fewer cars on the streets could affect the city in a positive direction, partly because it is better adapted for cycling and walking" [11]. Ruter were also asked if they want a car-free city centre, to this he replied that they would like public transport, cycling and walking to be given priority over private cars, which is also in accordance with the Oslo city council decision.

\subsection{Trade and service industry}

From a city life survey [16], 75\% of respondents said that they preferred shopping in the city centre shops instead of shopping malls (note: the survey was conducted in the city centre). A shopping centre has great competitiveness; it is managed professionally, well organized and it has the opportunity to give the shops good conditions. City centre shopping malls on the other hand can be a big draw, with its attractive retail offers. To get a varied and attractive trade environment in the city, is dependent on a variation of store types, especially big brand stores that attract customers. [17], [19], [20]. Shop owners overestimate how many customers who arrive by car. Surveys of transport used for shopping trips show that cyclists and pedestrians will return more often than motorists. Motorists are seen as the best customers because they leave more money per shopping trip. In the long run, however, it is not motorists who spend the most money, but public transport passengers and pedestrians [17], [19].

Gunnar Larssen, CEO of Oslo Commercial Association (OHF), told us during an interview that the business community is positive to a pedestrianized city centre, if thoughtfully planned. "The stores are counting their income every day, and their daily income will have to cover all expenses and any wages. Therefore, it must be planned so that it is predictable". Although Larssen favoured a pedestrianized city centre, he believed that closing streets would hurt stores for a period. During periods of reconstruction it is likely revenues go down, but rather increase when everything is in place. Larssen believes the long-term holistic view is missing. Needs will be different for different businesses, and all customers, deliveries and salesmen's visits must be maintained. Poor planning can worsen the situation. Larssen pointed out that the current situation is also at threat. 25 years ago, the city centre accounted for $30 \%$ of the turnover of trade in Oslo. This percentage has been halved as major customer groups are drawn to malls outside the centre. Larssen says that their desire is to organize the centre of Oslo in the same way as a shopping mall, with a central leader who can promote the entire diversity. Larssen speculates about how the situation will be in 10 or 20 years. Do we order the goods in the store and get it shipped home, or do we pick it at a warehouse outside the city? Home delivery of goods will also make customers more flexible; they can, for example, be going out to eat after a shopping trip without bringing their loaded shopping bags. What is important in such a situation, is that shops take the order from the customer, while being in the store. By all means, it must not be so that the customer visits and sees what's in the store, only to go home and order it over the internet from other shops. With these goals, one can have all the various downtown shops, from small-scale trade to furniture stores. Larssen welcomes the future and believes using the city in a new way will increase trade and improve service. Along with the Oslo city council, OHF has agreed to participate in a joint study tour of European cities to look for solutions there. "To make an impact, we have to show commitment, and invite ourselves. 
OHF has presented solutions for the city council and given concrete examples of various proposals, such as a parking garage adjacent to the pedestrian network". A major reason why there are few customers using cars in central Oslo, is lack of parking possibilities, parking-garages located in the wrong place, and over-pricing, Larsen claims. On whether OHF wants a pedestrianized city centre the answer is yes, if action is taken for everyone who uses the city. "We want more pedestrianized streets, several car-free areas, where the city is also available for customers who come by car... We want to use several parking garages that face the pedestrian network" [11].

\subsection{Goods deliveries}

Within Ring 1, there is a significant number of offices, service industries and shops that are totally dependent on goods deliverance. There are a number of challenges related to goods delivery by car in Oslo. Mobility is limited by traffic jams and cars illegally parked in deliverance spaces. Shops inconveniently placed, and many different actors who supply few stores within varying opening hours, reduces effectiveness. In 2012-2014 the project "Project Green City-distribution in Oslo" (GBO) was run. The project had as main objective to develop environmentally friendly and efficient distribution solutions in downtown Oslo through better utilization of available road space, better utilization of days and weeks, demonstrating the use of environmentally friendly and energy efficient vehicles, and unmanned inventories [21]. It also looked at the possibility of alternative delivery and it was planned to establish a temporary distribution centre in downtown Oslo [22]. To assess the feasibility of this, the Institute of Transport Economics (TØI) conducted a survey among goods recipients and carriers. Results shows that the largest share of goods in the city centre are delivered between 09:00 am and 1:00 pm. In the city centre there are two major pedestrian areas periods - the pedestrian network in and around the main street (Karl Johans gate) where goods delivery must take place during the period 00:00 am-11:00 am, and Aker Brygge, previously a brownfield area, where goods delivery is only allowed 07:00 am-11:00 am. Aker Brygge has physical barriers for preventing cars driving into the pedestrian streets after 11:00 am. The same does not apply to pedestrian streets around Karl Johans gate, and vehicles can be observed driving around the area after 11:00 am despite the ban. Many shops in Karl Johans gate are not staffed until 10:00 am. This means that the largest proportion of deliveries must occur during the period from 10:00 am to 11:00 am. The TØI report put forward a hypothesis that carriers will have the opportunity to plan and optimize delivery routes if more stores accept goods before 10:00 am. The report stated that there are many benefits of limited delivery times, such as more timely and predictable deliveries and fewer emissions It would also be beneficial to the shops and street scene if there are fewer vehicles in circulation in shopping hours. Establishing a consolidation centre can be a measure to improve the efficiency of goods delivery. With such a centre outside Ring 1 vans may deliver goods there, and later they are loaded together onto another vehicle for distribution. If the quantity of goods is not too big, it is also possible to use environmentally neutral distribution agents such as trolley or electric bicycle [21].

From our mail correspondence with Sven Bugge, general manager of Contractors' Development and Competence Centre (LUKS), it became clear that for goods providers it will be advantageous with exclusion of private cars from the city centre. This is because traffic load goes down and the street area may be released for use by distribution vehicles. "The battle for the curb will be substantially less". Sven Bugge says that within the Ring 1 already there are large areas having strict time reductions for goods deliveries, especially at pedestrian network in and around the main street Karl Johan. If all deliveries within Ring 1 
must take place within restrictive time periods, he believes that corporate logistics systems would not have had trouble adding up. A prerequisite for the delivery of the goods under such time constraints is that recipients are staffed, when goods arrive at their business. The municipality must set standards for goods recipients that they relate to the same time limit as is imposed upon goods suppliers. LUKS has worked actively to move towards fossil-free deliveries the last 20 years. Asked whether they have considered the possibility of alternative delivery forms within Ring 1, he replied that it would be appropriate in some cases, but that one must distinguish sharply between deliveries of large amounts of volume-products with sometimes considerable weight, and small package shipments. The first category requires large vehicles, as this best addresses car drivers' safety conditions as well as a rational and environmentally friendly transport means. The other category can to a certain extent be served by couriers on bicycle. For goods to be brought out individually from a city terminal for cargo/goods distribution, The GBO-project demonstrated that there are a number of legal and practical issues that must be clarified. A pedestrianized city centre must integrate a logistics plan for goods deliveries and must include positive and motivational measures. Goods transport with large environmentally friendly vehicles must gain equal priorities as environmentally friendly public passenger transport (Euro6, hydrogen, biogas, HVO etc.) [11].

\subsection{Craftsmen}

Many craftsmen use the car as a toolbox where they store tools and necessary materials [23]. In the city council's declaration, it is stated that businesses will be invited to a dialogue on the implementation of the pedestrianized city centre. There is no specific mention of craftsmen [2].

Through email correspondence with Jomar Talsnes Heggdal of Construction Industries (BNL) we received some answers on how a pedestrianized city centre will affect their members. On the question of what conditions the city council must accept for BNL welcoming a car-free centre he replied: "On behalf of the members, we are concerned for commerce and craftsmen to deliver goods and provide services. They still need to be able to drive right up to the workplace, although it is inside the city centre. Without any exceptions, our time usage will increase and some projects will in practice be difficult to implement. This will lead to increased costs to customers, both public and private" [11]. Further, Heggdal stressed that the city council must carry out real impact assessments, and that the politicians must go to lengths to compensate for the inconvenience and any restrictions that a car-free city centre would result in.

\subsection{Association for disabled people}

According to Statistics Oslo (2012) 9.1\% of the population in the city were disabled, and $14.1 \%$ of Oslo's population total [1]. According to the municipal master plan named "Smart Safe Green" (2015), an objective will be that "Growth in passenger transport should include are public transport, cycling and walking" [3]. Meanwhile, it must be ensured that: "Reform of the tram park and upgrading of the tram network will be implemented in the coming years. City trams will be user-friendly for all types of passengers, also elderly and disabled, and therefore there should be adequate stopping places in town" [3]. These are future goals, today much of the public transport services are not universally designed and the tram is the poorest of all. Within the Ring 1 there is today $90 \mathrm{HC}$ parking spaces [4]. The city council will remove 
parking spaces in conflict with the bike path development [2]. Whether HC parking spaces then will be removed due to this policy, is unclear

During our interview with Magnhild Sørbotten, regional manager for the Norwegian Association of the Disabled in Oslo, it became clear that the detailed provisions on a pedestrianized centre will be crucial to whether all will be able to take advantage of the city centre. According to her, a great many disabled people are wholly or partly dependent on the car. Today there is a huge pressure on the existing HC parking lots. Many want to use public transport, but unfortunately there are not many bus and tram stops designed for disabled persons. This means journeys must be planned carefully. It does not help if public transport is "somewhat" universal designed. One should be very clear about how to design, not to reduce the usability for disabled people in the city. When asked what it takes for them to agree to a pedestrianized city centre, she says "good planning". One must keep in mind that the city is composed of many people in different situations and phases of life. "The city in general is not particularly well organized. For the streets to be used by all, guidelines and not too many obstacles are needed. Often one imagines nightlife and street restaurants when talking about a car-free city centre. This can be a barrier for many. Wide sidewalks are needed if two people in wheelchairs or someone wheeling a stroller may pass each other". Public transport for all, along with several HC parking spaces and exemptions for driving downtown for certain people, are factors needed to not limit the self-expression of people with disabilities. Despite the fact that the city council has said that they would invite interested actors to engage in dialogue, the handicap association itself had to take the initiative for this. To the question of whether they welcome a pedestrianized city centre, the answer is neither yes or no. There will advantages and disadvantages. Persons suffering from severe asthma or COPD will experience improved air quality when there will be fewer cars in the streets.

\section{DISCUSSION}

Residents within Ring 1 can be affected both positively and negatively by a pedestrianized city centre. If restrictions on residents' driving are introduced before the public transport network is upgraded, this will cause many having more bothersome and time-consuming travels. But as city centres usually are the places with the best public transport links, the residents living inside the city centre will eventually get access to a wide range of transportation means. Dwellings in or near the city centre require only relatively few designated parking spaces for those who really are in need. One cannot remove the car parking completely without affecting people's opportunity to determine their own daily life and travel choices. Relevant alternatives could be car sharing schemes and high-quality routes and parking for bicycles. For residents, a pedestrianized city centre with fewer cars will cause less noise and air pollution. There will be greater opportunities for cultural events, and one will be able to travel safer in the streets. On the other hand, cultural events and more life in the streets lead to another type of noise for residents.

If the cars are removed from the city centre, it will be easier to facilitate other means of transport. One can assume that public transport will become even more congested than it is today, and therefore it is important that streets are made accessible to both pedestrians and especially cyclists. To avoid accidents and insecurity between these road user groups, this can be solved by having separate cycle paths, and speed restrictions for cyclists in pedestrian areas. The ability to bring your bike on the tram or subway will be absolutely necessary, since Oslo is a city with varied weather and uneven topography. For motorists, a pedestrianized city centre will cause restrictions on where to run. One can still accommodate motorists by producing their own tracks leading to parking garages and Oslo central railway station, or establishing more commuter parking outside the city centre. 
Surface parking requires a larger share of the downtown area than other forms of transport, which is undeserved when according to travel surveys the largest proportion of journeys happens with other means of transportation. Upon removal of street parking one can facilitate those who use the city centre most, such as cyclists.

So far, no plans are proposed to increase the capacity of public transport within Ring 1 until 2019. There might be a huge pressure on trams, subway and busses until plans for development are completed, though the press officer in Ruter thinks that the capacity will be satisfactory. The proportion of car travellers inside the city centre is relatively small, so if they choose public transit, this will not be adversely affected. It is important that the city centre also is better adapted for walking and cycling so that public transport need not take all the growth in journeys in the city. The flow of public transport in Oslo is likely to be affected in a positive way when the streets are less congested with cars.

There is no doubt that the retail industry will be affected by a traffic-free city centre. Whether this has a positive or negative impact depends on how the future of Oslo is planned. It is important to see what works in practice in other cities. In Freiburg and Nuremberg, as in Oslo, there was opposition from shopkeepers when the idea of a car-free city centre was lodged. OHF is admittedly positive to a pedestrianized city centre if it is implemented so that it becomes an attractive gathering place. Most respondents from the city life survey claim that they prefer to shop in the city centre. As this survey was carried out in the city centre, it is not surprising, and one can imagine that they are still going to prefer the centre after cars are banned. This is because the people who regularly shop inside Ring 1 are not motorists. When the streets are closed to cars, it will likely lead to a better urban environment. This in turn can cause the city centre to attract more customers. It is important to prevent them from driving to malls in the outskirt instead, when the city centre is closed to private vehicles. By organizing the city centre in the same way as a mall, they can make joint marketing of the area's car-free streets and vibrant atmosphere, as we saw in the cities visited. It is nevertheless an important criterion for OHF to ensure that those who visit the city by car still have the opportunity to shop, as this is one of the reasons they have shown commitment and cooperate with the city council. Garages in close connection with the pedestrian network would enable this, but also defeat the purpose of reducing emissions from car traffic. There might well be a difficult restructuring period for the stores, as experienced in the visited cities, but it is still expected that trade will increase after the pedestrianized centre is implemented. If shops adapt and act as showrooms so that more goods are ordered and delivered, this will probably lead to more deliveries of goods to private addresses, but also fewer deliveries into the city.

In order to maintain the diversity of supply in the city, goods delivery must be upheld even with a pedestrianized city centre. The planned pedestrian area in Oslo is significantly larger than the cities we visited, and therefore direct knowledge transfers may be difficult. It can be assumed that deliveries within Ring 1 will take place as today, or that all deliveries will be limited to certain periods of time. Limited delivery hours will enable goods distributors to optimize delivery routes. For this to be carried out, Oslo municipality must set the same restrictions for goods recipients and distributors. To reach the goal of a pedestrianized city centre and the given climate target, it is still necessary to limit the amount of goods distribution vehicles. If all goods delivery should take place in the morning hours, many distribution vehicles in circulation create conflict with public transport running frequently during this period. Since it is uncertain whether pedestrianized city centre will lead to any restrictions for goods delivery, it is difficult to determine the consequences. What is certain is that fewer cars will lead to better accessibility for distribution vehicles and prevent cars occupying delivery bays.

A pedestrianized centre could affect craftsmen negatively. Craftsmen rely on using their car to transport tools and materials. If they do not get access to a site, they could lose 
customers. As craftsmen are considered a necessity for many people and businesses inside Ring 1, it is natural to assume that they will have some access to this area. Yet if street parking is removed and they have to park in a garage, it may be difficult or impossible to transport large tools or materials. Oslo might, like other cities with pedestrianized city centres, provide craftsmen licenses to drive and park in the car-free zone. On the other hand, to apply for permission may be a time-consuming process that can be a problem for critical issues.

Accessibility for all people must be a primary goal in a pedestrian city centre. As the city council has stated that mobility impaired people should be provided for, it is natural to assume that some will be allowed to continue to drive in the city centre. Then one can also assume that the HC parking lots in the centre will remain. Removing other street parking will put great pressure on those parking lots. Some people are entirely dependent on the car, but to achieve climate objectives as many people as possible must make use of public transit. The municipal planning target for city trams to be user-friendly for all passengers, including the elderly and disabled, must be realised before the city centre is closed to cars. In Freiburg we observed that information boards clearly stated which trams are suitable for wheelchair users. Such measures should also be introduced in Oslo. Why the handicap association had to invite themselves to dialogue with the city council may indicate that the process is not quite started yet, and that there is still much that needs to be clarified. It is important to get user groups such as disability associations to participate at an early planning stage.

\section{CONCLUSION}

From the cities visited, we have observed that a car-free centre is not completely car-free. There will always be exceptions for certain user groups and stakeholders. The same must be true in Oslo, this is also evident from the Oslo city council's declaration providing exceptions for certain user groups and stakeholders. Changes should not come overnight, they should be planned and allow for acclimation for those affected.

Having a solid planning phase based on cooperation between politicians, the affected, and professionals will be more important than the goal of implementing the measure by 2019. If they succeed with good planning with thoughtful measures to ensure good accessibility for other transportation than private cars, this could potentially lead to a more vibrant urban environment in downtown Oslo - a city centre where pedestrians can roam freely and safely, and public transport can run unimpeded. With good planning processes, Oslo city centre will become a more sustainable city centre with less air and noise pollution, and it can become a city centre by that will increasingly attract visitors and shoppers. If the planners pay attention to the most affected stakeholders, it can also become a better city for all - to live, work, and play in.

\section{REFERENCES}

[1] Multiconsult, Det grønne skiftet - Utkast til Klima og energistrategi for Oslo, Oslo kommune, klima og energiprogrammet, Oslo, 2015.

[2] Johansen, R. et al., Plattform for byrådssamarbeid mellom Arbeiderpartiet, Miljøpartiet De Grønne og Sosialistisk Venstreparti i Oslo 2015-2019, Oslo, 2015.

[3] Oslo kommune, Smart, Trygg, Grønn, Kommuneplan 2015 - Oslo mot 2030, Samfunnsdel og byutviklingsstrategi, Oslo, 2015.

[4] Oslo kommune, Statistikkbanken, Oslo, 2016.

[5] Rydningen, U. \& Rolfsen, C.N., Making education on sustainable community planning tangible. Presented at Sustainable City 2016, Alicante, Spain. 
[6] Bonanomi, L. et al., Town and infrastructure planning for safety and urban quality for pedestrians: A city for pedestrians: Policy-making and implementation, ed. D. Fleury, European Commission: Brussels, p. 298, 2001.

[7] Crawford, J.H., Carfree Cities, International Books: Utrecht, p. 324, 2002.

[8] Tønnesen, A., Meyer, S.F., Skartland, E.G. \& Sundfør, H.B., Europeiske byer med bilfrie sentrum (TØI rapport 1476/2016), Transportøkonomisk institutt: Oslo, 2016.

[9] Karppinen, S. et al., Reclaiming city streets for people Chaos or quality of life?, European Commission, Directorate-General for the Environment, 2004.

[10] Leite, T. \& Nielsen, G., Integrert transport og byplanlegging i Freiburg, Tyskland: Stø kurs mot bedre miljø. Samferdsel, 8, p. 5, 2008.

[11] Høynes, R.C., Kolltveit, L.W. \& Thorvaldsen K., Bilfritt sentrum i Oslo - et sentrum for alle, BSc Thesis, Department of Civil Engineeing \& Energy Technology, Oslo and Akershus University College of Applied Sciences: Oslo, 2015.

[12] Hjorthol, R., Engebretsen, Ø. \& Uteng, T.P., Den nasjonale reisevane-undersøkelsen 2013/14 - nøkkelrapport (TØI rapport 1383/2014), Transportøkonomisk institutt: Oslo, 2014.

[13] Ellis, I.O. et al., Reisevaner i Osloområdet. En analyse av den nasjonale reisevaneundersøkelsen 2013/14, Urbanet Analyse, Rapport 218. Oslo, 2015.

[14] Bjørnland, D.C. et al., God boligfortetting i Oslo - Eksempelsamling, Oslo kommune, Plan og bygningsetaten: Oslo, 2012.

[15] Cowi, A.S., Hvilke virkemidler monner for økt andel kollektivreiser, sykling og gange?, Prosam rapport nr 214, Prosam: Oslo, 2015.

[16] Gehl Architechts, Spørre-skjemaundersøkelsen, Bylivsundersøkelse Oslo sentrum 2014, Copenhagen, 2014.

[17] Olimstad, M. \& Gjellebæk, I., Hva betyr gateparkering for handelen? (Statens vegvesen rapporter Nr. 440), Statens vegvesen: Oslo, 2015.

[18] Homleid, T. et al., Behovs-analyse (KVU Oslo-Navet), Jernbaneverket, Statens vegvesen og Ruter AS: Oslo, 2015.

[19] Visnes, K., Tennøy, A. \& Tønnesen, A., Handel, tilgjengelighet og bymiljø i sentrum, Plan, 47(5), pp. 56-61, 2016.

[20] Tennøy, A., Tønnesen, A. \& Øksenholt, K.V., Kunnskapsstatus Handel, til-gjengelighet og bymiljø i sentrum, (TØI rapport 1400/2015), Transport-økonomisk institutt: Oslo, 2015.

[21] Johansen, B.G., Andersen, J. \& Levin, T., Effekt og konsekvensanalyse av tiltak relevante for Oslo - Forhåndsevaluering av prioritering av tilgang til vareleverings-lommer og alternative leveringstidspunkt (ТØI rapport 1338/2014), Transport-økonomisk institutt: Oslo, 2014.

[22] Sund, A.B. et al., Grønn bydistribusjon i Oslo, SINTEF Teknologi og samfunn - Transport, Trondheim, 2015.

[23] Sæter, R.A.L., Bilfritt Oslo - absolutt en mulighet, Online. https:// www.romeiendom.no/rom-konferansen-2016. Accessed on: 23 Mar. 2017. Presented at the Bilfritt Oslo - utopi eller mulighet, Oslo, 2016. 